\title{
フェライト系融体中の $\mathrm{CO}_{2}$ の溶解度および その粘性におよぼす影響
}

\author{
角田成夫* 森永健次“柳ヶ瀬 勉*
}

J.Japan Inst. Metals, Vol.46, No.4(1982), pp.369-373

Solubility of $\mathrm{CO}_{2}$ in Ferrite Slag Melts and It's Effect on the Viscosity

Shigeo Sumita*, Ken-ji Morinaga* and Tsutomu Yanagase*

The solubility of $\mathrm{CO}_{2}$ in $\mathrm{Na}_{2} \mathrm{O}-\mathrm{Fe}_{2} \mathrm{O}_{3}$ and $\mathrm{CaO}-\mathrm{Fe}_{2} \mathrm{O}_{3}$ systems and its effect on the viscosity have been measured to elucidate the behavior of $\mathrm{CO}_{2}$ in these melts. The quantitative analysis of $\mathrm{CO}_{2}$ content by the use of infra-red absorption spectra has been proposed for the slag systems. The solubility of $\mathrm{CO}_{2}$ in the $\mathrm{CaO}-\mathrm{Fe}_{2} \mathrm{O}_{3}$ system and the silicate melt is less than $1 \mathrm{~mol} \% \mathrm{CO}_{2}$, while in the $\mathrm{Na}_{2} \mathrm{O}-\mathrm{Fe}_{2} \mathrm{O}_{3}$ system it is $5-20 \mathrm{~mol} \% \mathrm{CO}_{2}$ due to the strong basicity of the melts. The effect of $\mathrm{CO}_{2}$ on the viscosity of $\mathrm{Na}_{2} \mathrm{O}-\mathrm{Fe}_{2} \mathrm{O}_{3}$ system is almost the same as that of $\mathrm{SiO}_{2}$, which indicates that the constitution of $\mathrm{CO}_{2}$ in $\mathrm{Na}_{2} \mathrm{O}-\mathrm{Fe}_{2} \mathrm{O}_{3}$ system can be assumed to be of a complex anion type species with a unit form of $\mathrm{CO}_{3}{ }^{2-}$ such as $\mathrm{SiO}_{4}{ }^{4-}$ in silicates.

(Received October, 31, 1981)

\section{I. 緒霉}

最近，脱リン，脱硫を同時に行うことができる $\mathrm{Na}_{2} \mathrm{CO}_{3}$, $\mathrm{CaCO}_{3}$ をフラックスとして精鍊に用いる試み(1)(2)や $\mathrm{SiO}_{2}$ を含まないフェライト系スラグを製鍱に用いたプロセスの 開発(3)など，新しい我のフラックス，スラグが金属製錬， 精製に賞用される傾向にある。 $\mathrm{SiO}_{2}$ を含む従来のスラグに は末分解の残留 $\mathrm{CO}_{2}$ や気相中からの $\mathrm{CO}_{2}$ の溶解は非常に 少ない(4)。しかし， $\mathrm{SiO}_{2}$ を含まない新しい系のフラック ス，スラグには多くの未分解の $\mathrm{CO}_{2}$ があり， $\mathrm{Na}_{2} \mathrm{CO}_{3}$ は注 とんど分解，気化せずに融体になる(1)(2)。このような $\mathrm{CO}_{2}$ が融体中炕どのよう形態で存在し，融体の物性にどの上 うな影響を与えるかの詳細な報告はない，CはSi と元素 周期表で同じN B 族にあり， $\mathrm{C}^{4+}$ は Si行と同様な挙動をす ると予測される。事実, 炭酸塩融体の赤外線発光スペクト $\varkappa^{(5)}, \mathrm{X}$ 線回折 ${ }^{(6)}$ ，同系のガラス化実験 ${ }^{(7)}$ などから，炭酸 塩融体中では， $\mathrm{C}^{4+}$ は酸素 3 配位をとり， $\mathrm{CO}_{3}{ }^{2-}$ として存 在していると考えられている。

本研究に招いては， $\mathrm{CaO}-\mathrm{Fe}_{2} \mathrm{O}_{3}, \mathrm{Na}_{2} \mathrm{O}-\mathrm{Fe}_{2} \mathrm{O}_{3}$ 系融体中の $\mathrm{CO}_{2}$ の挙動を明らかにするため，赤外線分光法による残留 あるいは，溶解 $\mathrm{CO}_{2}$ の定量法を確立し， $\mathrm{CO}_{2}$ の残留量，溶 解量を測定， $\mathrm{CO}_{2}$ が同系融体の粘度飞招よばす影響を検討 した.

\section{II. 実 験 方 法}

試料用試薬には，特級試薬の $\mathrm{Na}_{2} \mathrm{CO}_{3}, \mathrm{CaCO}_{3}, 1$ 級試薬
の石英砂， $\mathrm{Fe}_{2} \mathrm{O}_{3}$ を用いた。各試薬を所定の組成となるよ う精科混合し，白金ルッボを用いて $\mathrm{CO}_{2}$ をコントロール した雾囲気中で溶解した。溶解した試料を急冷し，赤外線 分光器 (島津製 IR- 440 型)での $\mathrm{CO}_{2}$ 分析試料とした。分析 法の詳細については，III.1。に記述する。

粘度の測定には，ルッボ回転法を用いた。本研究室で自 作した，雱用気の調整が可能な装置で，装置の詳細はすで に報告した ${ }^{(8)}$.

\section{III. 結果と考察}

\section{1. 赤外線分光器による $\mathrm{CO}_{2}\left(\mathrm{CO}_{3}{ }^{2-}\right)$ の分析}

スラグ中の $\mathrm{C}, \mathrm{CO}_{2}$ の分析法には，鉄鋼中のCの分析法 を応用した然焼法 ${ }^{(9)} か ゙$ 西る。しかし， $\mathrm{CO}_{3}{ }^{2-}$ のよ5に酸素 と結合し，スラグの構成成分として他の成分と強く結合し ているようなCが，酸素気流中ての然焼で，すべて気相に 移行するかは疑問であり，試料組成によっては，かなりの $\mathrm{CO}_{2}\left(\mathrm{CO}_{3}{ }^{2-}\right)$ が残存すると考光られる。そこで本研究では赤 外線分光器により，スラグ中の $\mathrm{CO}_{2}\left(\mathrm{CO}_{3}{ }^{2-}\right)$ を定量するこ とを試みた。

Fig.1 亿本定量法に関する赤外線吸収スペクトルを示し た。スペクトルは，KBr 錠威法により測定した。図にお いて(a)は定量に用いる試料による吸収スペクトルの一例 であり，(b)は $\mathrm{Fe}_{2} \mathrm{O}_{3}$, (c) は $\mathrm{Na}_{2} \mathrm{CO}_{3}$ ，(d) は $\mathrm{SiO}_{2}$ の各純粋 試薬の吸収スペクトルである。(b) に示すよらに, $\mathrm{Fe}_{2} \mathrm{O}_{3}$ は 分析火用いる波数 $800 \sim 1500 \times 10^{2} \mathrm{~m}^{-1}\left(800 \sim 1500 \mathrm{~cm}^{-1}\right)$ K

* 九州大学総合理工学研究科材料開発工学専攻 (Department of Materials Science and Technology, Graduate School of Engineering Sciences, Kyushu University, Fukuoka) 


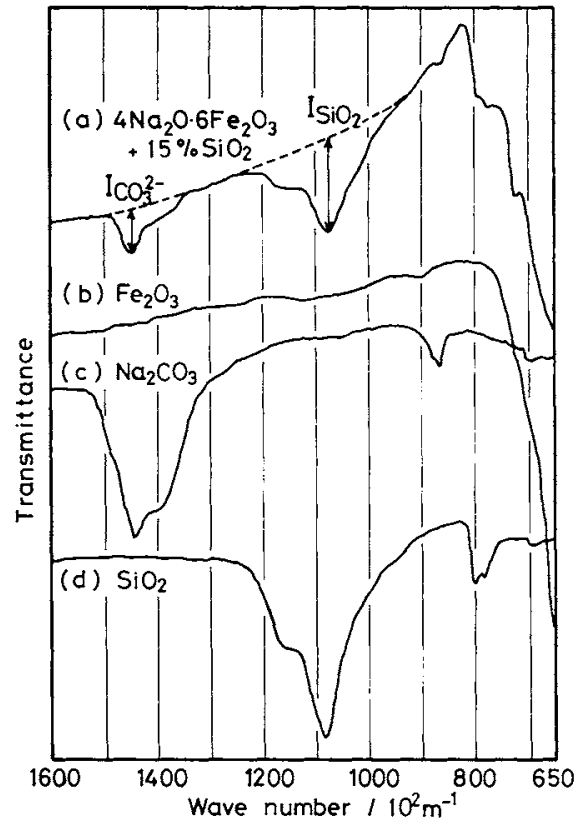

Fig. I Infra-red absorption spectra used for measuring the $\mathrm{CO}_{2}$-content in ferrite slag.

は吸収を示さない(10). (c) は $\mathrm{Na}_{2} \mathrm{CO}_{3}$ 中の $\mathrm{CO}_{3}{ }^{2-}$ の吸收ス ペクトルで, 約 $1450 \times 10^{2} \mathrm{~m}^{-1}\left(1450 \mathrm{~cm}^{-1}\right) \mathrm{K}, \mathrm{CO} の \nu_{3}$ 伸 縮振動による吸收ピークを示す。 $\mathrm{CaCO}_{3}$ 中の $\mathrm{CO}_{3}{ }^{2-}$ 吸収 スペクトルも，注涪同様の吸収ピークを示した。この $\mathrm{CO}_{3}{ }^{2-}$ Kよる吸収ピークの強度から，スラグ中の $\mathrm{CO}_{2}$ $\left(\mathrm{CO}_{3}{ }^{2-}\right)$ を定量する。年のために，内部標準として，試薬 の $\mathrm{SiO}_{2}$ 添加した。 (d) に示す上5に， $\mathrm{SiO}_{2}$ は約 $1100 \times$ $10^{2} \mathrm{~m}^{-1}\left(1100 \mathrm{~cm}^{-1}\right) 飞 \nu_{3}$ 伸縮振動による吸収ピークを示 し， $\mathrm{CO}_{2}\left(\mathrm{CO}_{3}{ }^{2-}\right)$ の吸收ピークとは，汪とんど重なり合わ ない。(a) 唗量に用いたスペクトルの一例で， $4 \mathrm{Na}_{2} \mathrm{O}$. $6 \mathrm{Fe}_{2} \mathrm{O}_{3}$ の溶解急冷後 300 mesh 程度化粉碎した陚料 $1 \times$ $10^{-3} \mathrm{~kg}$ に対し，300 mesh 程度に粉磪した $\mathrm{SiO}_{2} 1.5 \times 10^{-4}$ $\mathrm{kg}$ を添加し，十分混合した試料の赤外線吸収スペクトル である。このスペクトルから， $1450 \times 10^{2} \mathrm{~m}^{-1}\left(1450 \mathrm{~cm}^{-1}\right)$ 付近の $\mathrm{CO}_{2}\left(\mathrm{CO}_{3}{ }^{2-}\right)$ の吸收ピークの高さ(強度, $\mathrm{I}_{\mathrm{CO}_{3}{ }^{2-}}$ 記す) と $1100 \times 10^{2} \mathrm{~m}^{-1}\left(1100 \mathrm{~cm}^{-1}\right)$ 付近の $\mathrm{SiO}_{2}$ の吸收ピー

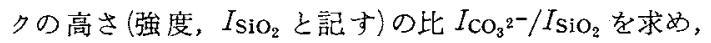
西らかじめ作成した㭘量線から $\mathrm{CO}_{2} \mathrm{~mol} \%$ 求めた。検量 楾を各ピークの面積の比を用いて求める方法についてむ 試みた。この場合も検量線はほぼ直線で，強度比の場合々 同様であった，本研究においては，簡便のため高さの比を 强度比々して採用した。

Fig.2 2 検量線を示す. $\mathrm{Na}_{2} \mathrm{CO}_{3}, \mathrm{CaCO}_{3}, \mathrm{Fe}_{2} \mathrm{O}_{3}$ の試薬 を, 300 mesh 程度に粉确 L, 所定量を混合, $\mathrm{CO}_{2}$ 含量既 知の試料を調製し，この試料 $1 \times 10^{-3} \mathrm{~kg}$ に対して，300 mesh 程度飞粉硪した $\mathrm{SiO}_{2} 1.5 \times 10^{-4} \mathrm{~kg}$ を内部摽準として 添加し，十分に混合したものの赤外線吸収スペクトルか

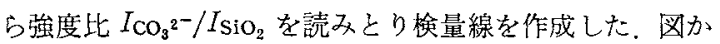

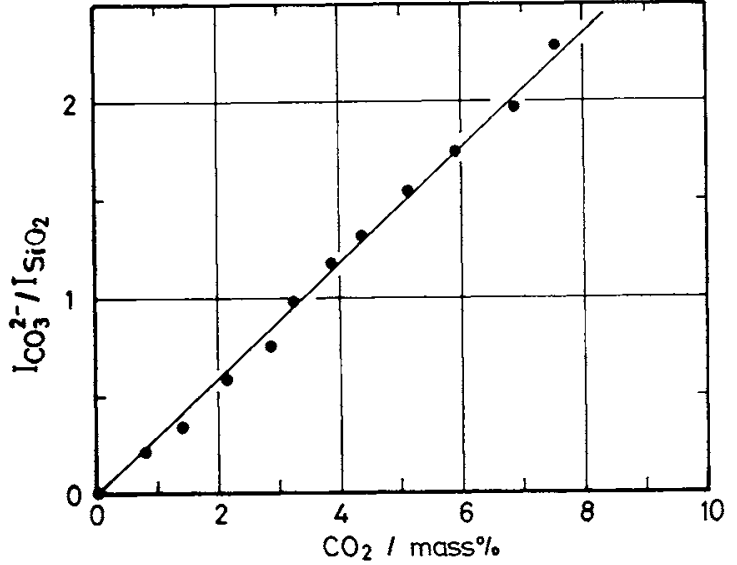

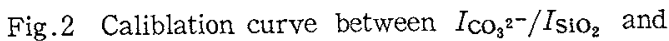
$\mathrm{CO}_{2}$-content.

ら明らかなよう飞, $I_{\mathrm{CO}_{3}{ }^{-}} / I_{\mathrm{SiO}_{2}}$ と $\mathrm{CO}_{2}$ mass\%は, 上い直 線珄を示した，分析の誤美は，赤外線吸収スペクトルの測 定を繰り返して行うとさ生ずる愦差と、スペクトルから 強度比を読及とるとき生ずる䛊垭が大きかったが，いず れも $\mathrm{CO}_{2}$ mass\%で $1 \%$ 以内であった。

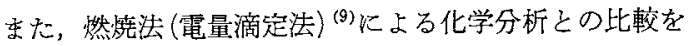
行った，赤外法の検量線作成と同様な $\mathrm{Na}_{2} \mathrm{CO}_{3}, \mathrm{Fe}_{2} \mathrm{O}_{3}$ を混 合した試料については，然焼法により泳ぼ理論量の $\mathrm{CO}_{2}$ $\left(\mathrm{CO}_{3}{ }^{2-}\right)$ を定量できた。しかし，一度溶解させて急冷後粉 挽した試料须いては，たと充ば， $\mathrm{CO}_{2}$ mass\%は $1623 \mathrm{~K}$ に斗いて溶解した $3 \mathrm{Na}_{2} \mathrm{O} \cdot 7 \mathrm{Fe}_{2} \mathrm{O}_{3}$ では赤外法で $1.4 \%$ ，燃 娈法で $0.06 \%, 6 \mathrm{Na}_{2} \mathrm{O} \cdot 4 \mathrm{Fe}_{2} \mathrm{O}_{3}$ では赤外法で $13.6 \%$ ，燃接 法で $6.05 \%$ の值を得た。こ机らの結果から，赤外法による 值が然焼法による值より大きくなっていることがかかる が，然焼法に祘いては検出されない残留のCが存在するこ とが推定される。

\section{2. $\mathrm{CO}_{2}\left(\mathrm{CO}_{3}{ }^{2-}\right)$ の溶解量}

気相中の $\mathrm{CO}_{2}$ がスラグ融体へ溶解する量の経時変化を 測定し, Fig.3 亿示した。図は， $\mathrm{Na}_{2} \mathrm{O} / \mathrm{Fe}_{2} \mathrm{O}_{3}$ (含 $\mathrm{CO}_{2}$ ) = $50 / 50$ の試料老短時間溶融し, 老の試料 $\left(\mathrm{CO}_{2}\right.$ 約 $\left.3.5 \mathrm{~mol} \%\right)$ を $\mathrm{CO}_{2}$, Air 中などの所定の雾囲気で,シリコニット炉中 で白金ルツボ (内径 $34 \mathrm{~mm}$ )を用いて溶融し，各時間で急冷 乙, 赤外線分光法により求めたスラグ中の $\mathrm{CO}_{2}$ 量の経時 変化を示した，罒から明らかな上らに，本実験条件では， 約 $3.6 \mathrm{ks}(1 \mathrm{~h})$ 後に平衡值に達したと考光られる， $\mathrm{CO}_{2}$ 雾团 気では， $\mathrm{CO}_{2}$ の溶解が，Air 中では $\mathrm{CO}_{2}$ の気相への移行が 観測される。 $\mathrm{Na}_{2} \mathrm{CO}_{3} / \mathrm{Fe}_{2} \mathrm{O}_{3}=50 / 50$ の混合試料を $\mathrm{CO}_{2}$ 雾囲 気中で溶解しても，約 $3.6 \mathrm{ks}(1 \mathrm{~h})$ 後には $\mathrm{CO}_{2}$ 約 $5 \mathrm{~mol} \%$ となり，図の $\mathrm{CO}_{2}$ の溶解量と浪涪一致した。このことか ら次式の反応が可逆的㶤起っていると考完られる.

$$
\mathrm{CO}_{2}+\mathrm{O}^{2-} \rightleftarrows \mathrm{CO}_{3}{ }^{2-}
$$

次化, $\mathrm{CO}_{2}$ の溶解量に打よぱすスラグの系拉よび組成の 影響を調べた， $\mathrm{CO}_{2}$ 雲畔気中での結果のみ Fig.4 江示し 


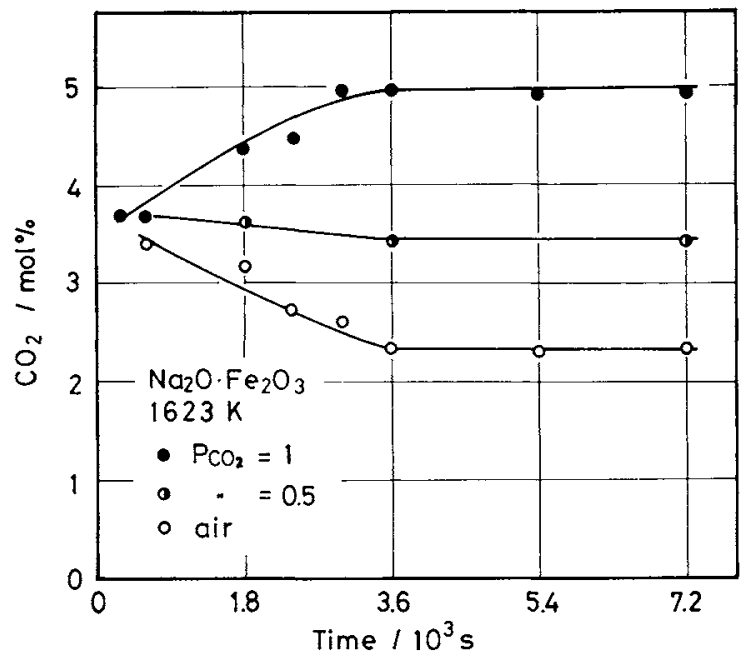

Fig.3 Change in $\mathrm{CO}_{2}$-content in $\mathrm{Na}_{2} \mathrm{O} \cdot \mathrm{Fe}_{2} \mathrm{O}_{3}$ melt versus melting time and atmosphere.

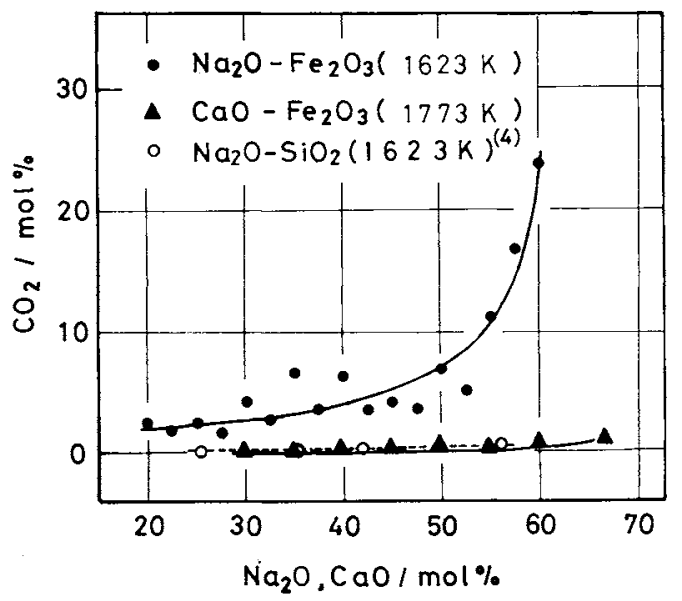

Fig.4 Relation between the solubility of $\mathrm{CO}_{2}$, and $\mathrm{Na}_{2} \mathrm{O}$ and $\mathrm{CaO}$ contents in ferrite slag.

た。 $\mathrm{Na}_{2} \mathrm{O}-\mathrm{SiO}_{2}$ 系 $(1623 \mathrm{~K})^{(4)}$ 融体中の $\mathrm{CO}_{2}$ の溶解量は， $0.1 \mathrm{~mol} \%$ 以下であり， $\mathrm{CaO}-\mathrm{Fe}_{2} \mathrm{O}_{3}$ 系 $(1773 \mathrm{~K})$ と同じ程度 の溶解量である。しかし， $\mathrm{Na}_{2} \mathrm{O}-\mathrm{Fe}_{2} \mathrm{O}_{3}$ 系 $(1623 \mathrm{~K})$ は，図 に示すよらに, $\mathrm{Na}_{2} \mathrm{O}$ の量の增加に伴い， $\mathrm{CO}_{2}$ は增加する。 $\mathrm{Na}_{2} \mathrm{O} / \mathrm{Fe}_{2} \mathrm{O}_{3}<1$ では約 $2 \sim 5 \mathrm{~mol} \%, \mathrm{Na}_{2} \mathrm{O} / \mathrm{Fe}_{2} \mathrm{O}_{3}>1$ では約 8 22 $\mathrm{mol}_{\%} \% \mathrm{CO}_{2}$ が溶解する. 式(1)の平衡定数を $K$ と 尚と,

$$
K=\frac{p_{\mathrm{CO}_{2}} \cdot a_{\mathrm{O}^{2}}}{\left[\mathrm{C}_{\mathrm{CO}_{3}{ }^{2-}}\right]}
$$

ここで, $p_{\mathrm{CO}_{2}}=1, a_{\mathrm{O}^{2}}$ を $\mathrm{O}^{2-}$ の活量, $\left[\mathrm{C}_{\mathrm{CO}_{3}{ }^{2}}\right]$ を $\mathrm{CO}_{3}{ }^{2-}$ の 濃度とすると, 次式になる。

$$
\left[\mathrm{C}_{\mathrm{CO}_{3}{ }^{2}}\right]=\frac{a_{\mathrm{O}^{2-}}}{K}
$$

式(3)から，融体中の $\mathrm{O}^{2-}$ 活量，なな方ち篮基度を定量的 に論ずることは，Kの系および組成による見積りができな い限り不可能である(4)。乙かし，定性的には， $\mathrm{Na}_{2} \mathrm{O}-\mathrm{Fe}_{2} \mathrm{O}_{3}$
系融体は， $\mathrm{CaO}-\mathrm{Fe}_{2} \mathrm{O}_{3}$ 系や他の珪酸塩融体に比べ，高い塩 基度をるつと考光られ。。

\section{3. 溶解 $\mathrm{CO}_{2}$ の粘度におよばす影響}

Fig.5 和よびFig.6は，それぞれ $\mathrm{Na}_{2} \mathrm{O}-\mathrm{Fe}_{2} \mathrm{O}_{3}$ 系拉よび $\mathrm{CaO}-\mathrm{Fe}_{2} \mathrm{O}_{3}$ 系における $\mathrm{CO}_{2}$ 雾国気と空気中での粘度の测 定結果を示す．空気雾囲気での測定結果は，前報 (11) で報 告したものである. $\mathrm{CO}_{2}$ 中での両系の测定結果から ln と $1 / T$ は直線関係を示し, $\mathrm{CO}_{2}$ 中での粘度值は, 空気中 のをれよりも、いずれる大きな值を示し，また，アレニウ

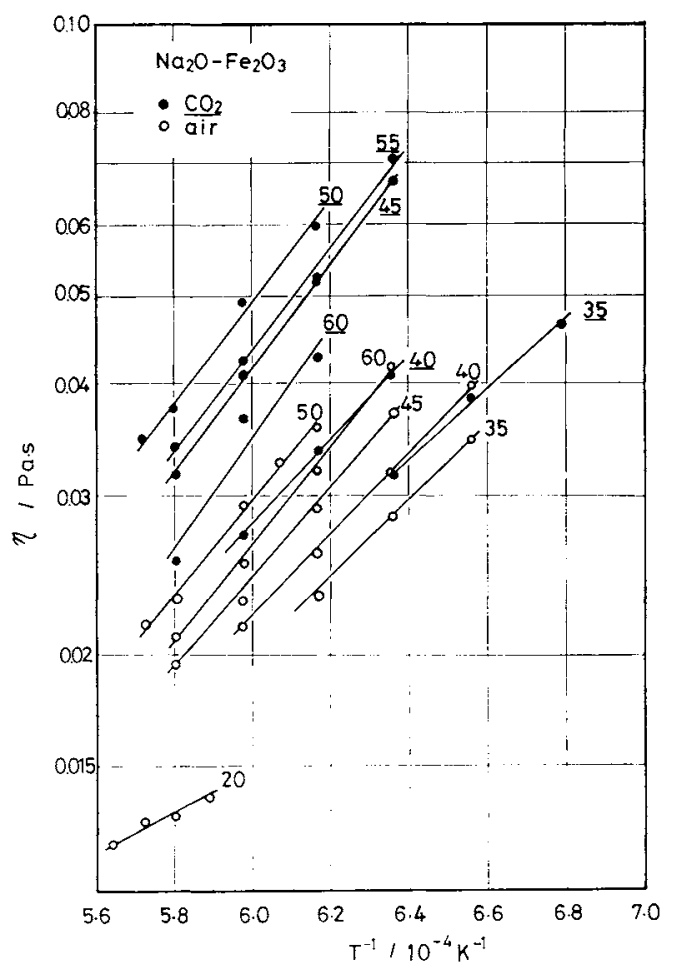

Fig.5 Viscosity of $\mathrm{Na}_{2} \mathrm{O}-\mathrm{Fe}_{2} \mathrm{O}_{3}$ melts under $\mathrm{CO}_{2}$ and air atmosphere.

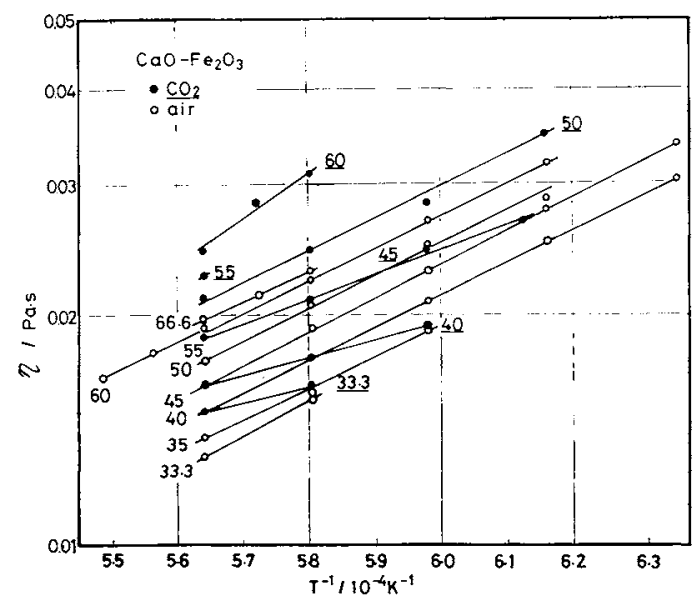

Fig.6 Viscosity of $\mathrm{CaO}-\mathrm{Fe}_{2} \mathrm{O}_{3}$ melts under $\mathrm{CO}_{2}$ and air atmosphere. 
スの式から求めた粘性の活性化エネルギーも約 $20 \mathrm{~kJ} / \mathrm{mol}$ 高い值であった，このことは，溶解した $\mathrm{CO}_{2}$ が $\mathrm{SiO}_{2}$ のよ らに鍇陰イホンとして存在し，粘度を高くしていると推定 される。

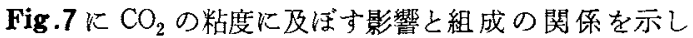
た。 $\mathrm{Na}_{2} \mathrm{O}-\mathrm{Fe}_{2} \mathrm{O}_{3}$ 系の粘度の極大值については，既報で詳 細に報告(11)(12) している，両系においても， $\mathrm{CO}_{2}$ 雾团気中

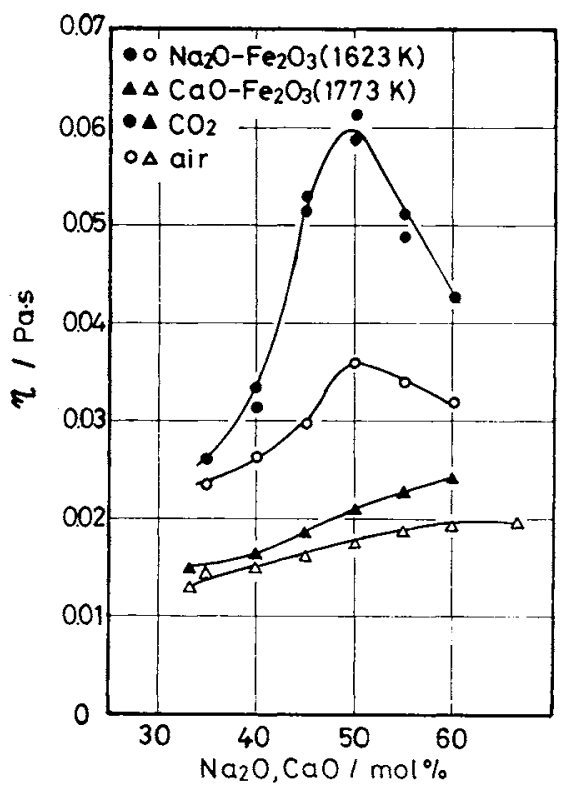

Fig.7 Viscosity of ferrite slag as a function of $\mathrm{CaO}$ and $\mathrm{Na}_{2} \mathrm{O}$ contents under $\mathrm{CO}_{2}$ and air atmosphere.

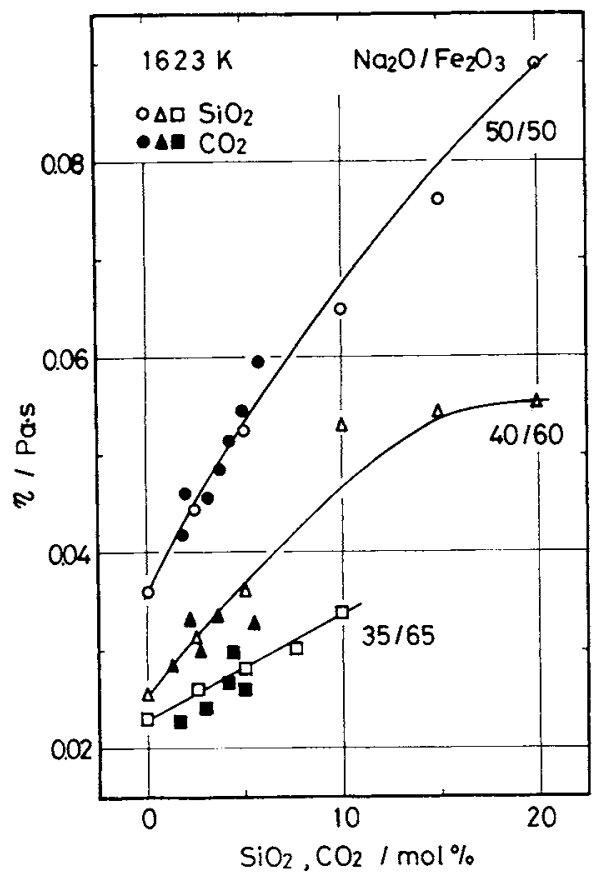

Fig.8 Effect of $\mathrm{CO}_{2}$ and $\mathrm{SiO}_{2}$ content upon the viscosity of $\mathrm{Na}_{2} \mathrm{O}-\mathrm{Fe}_{2} \mathrm{O}_{3}$ melts.
での粘度の組成変化は, 空気中と類似し，やや高い粘度值 を示した， $\mathrm{CO}_{2}$ 霑囲気での測定試料中には空気中より $\mathrm{Fe}^{2+} / \mathrm{Fe}$ total が最大数\%増加しているが，化学分析の結 果, $1623 \mathrm{~K}$ から急冷した $3 \mathrm{Na}_{2} \mathrm{O} \cdot 7 \mathrm{Fe}_{2} \mathrm{O}_{3}$ 組成に数いて最大 で， $\mathrm{CO}_{2}$ 雲囲気中，空気中でそれぞれ $11.2 \%, 3.2 \%$ であ った． 10 数\%の $\mathrm{Fe}^{2+}(\mathrm{FeO})$ の生成は，粘度をやや低下さ せる效果があるが，図に示寸よらに，溶解した $\mathrm{CO}_{2}$ によっ て粘度は，いずれも増加してまり，ここでは数\% $\mathrm{Fe}^{2+} に$ よる粘度の変化は無視できる。

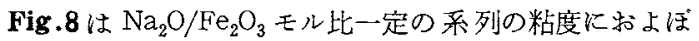
す $\mathrm{SiO}_{2}$ 添加量の影響と $\mathrm{CO}_{2}$ 溶解量の影響を示したもので ある. $\mathrm{CO}_{2}$ 䨌囲気和よび $\mathrm{CO}_{2}$ と $\mathrm{N}_{2}$ の任意の混合䨌团気を 用いてスラグ中の $\mathrm{CO}_{2}$ 量を変化させた，粘度測定装置が 完全㟳封系でないため， $\mathrm{CO}_{2}$ 分圧を正確に規定でさなかっ たが，すべての測定融体を急冷し，赤外線分光器により $\mathrm{CO}_{2}$ の溶解量を定量し，横軸の $\mathrm{CO}_{2}$ mol\%量とした。

图から明らかなよ $5 \mathrm{r}, \mathrm{CO}_{2} \mathrm{~mol} \%$ 量と $\mathrm{SiO}_{2}$ 添加量の粘 度におよぼす影響はほとんど一致した。このことは，気相 中から溶解した $\mathrm{CO}_{2}$ や残存している $\mathrm{CO}_{2}$ が $\mathrm{SiO}_{4}^{4-}$ あるい はその重合体と同様に $\mathrm{CO}_{3}{ }^{2-}$ を基本単位となる錯陰イオン を形成し，スラグ中に溶解していることを示している。

\section{4. $\mathrm{CO}_{2}$ の本スラグ中での形態}

III.1.で示した赤外楾吸収スペクトルは， $\mathrm{CO}_{3}{ }^{2-}$ として 存在する $\mathrm{CO}_{2}$ と同様, $\mathrm{CO}_{2}$ 分子として溶解あるいは付着 している $\mathrm{CO}_{2}$ b含めて測定される，従来から，スラグ中 に存在する $\mathrm{CO}_{2}$ は，式(1)k示したよらに， $\mathrm{CO}_{3}{ }^{2-}$ として 溶解すると考えられている ${ }^{(4)}$. 本研觉に执いて子，赤外線 吸収スペクトルから求めた $\mathrm{CO}_{2}$ 量が, Fig.8に示すよう に, $\mathrm{SiO}_{2}$ 添加量亡同様の粘度への効果があることから， $\mathrm{CO}_{3}{ }^{2-}$ を基本単位とする錯陰イオンを形成して存在するる のと考えられる、 $\mathrm{CO}_{3}{ }^{2-}$ 錯陰イオンの重合度等の形態につ いては，赤外線眀収ピークのシフトや他の分光法で詳細に 研究する必要がある。本実験範囲内である $\mathrm{CO}_{2}$ 量 $\mathrm{SiO}_{2}$ 量 が少ない領域に怙いては， $\mathrm{SiO}_{2}$ は大きな重合体を示さず, 溶解した $\mathrm{CO}_{2}$ は, $\mathrm{CO}_{3}{ }^{2-}$ を基本単位とした錯陰イオンで存 在し， $\mathrm{SiO}_{2}$ と同様の挙動をするるのと推定される。

\section{IV. 結言}

フェライト系融体中の溶解，兴残存する $\mathrm{CO}_{2}$ の挙 動を明らかにするため，まずスラグ中の $\mathrm{CO}_{2}$ 含有量を赤 外線分光器を用いて定量する方法を確立した。また，溶解 残存する $\mathrm{CO}_{2}$ は，本測定範囲内でスラグ中に添加された $\mathrm{SiO}_{2}$ と同椂の影慧を粘度に与えた。このことから，スラグ 中の $\mathrm{CO}_{2}$ は $\mathrm{CO}_{3}{ }^{2-}$ 基本単位とする錯陰イオンの形態で 存在すると推定した。

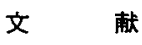

（1）井上 亮，水渡英昭：鉄と鋼，65(1979)，1838. 
（2）水渡英昭：日本金属学会会報，18(1979)，490.

（3）永野 健：鉄と鋼，63(1977)，1911。

(4) M.L.Pearce : J.Amer.Ceram.Soc., 47 (1964) ,342; $48(1965), 175$.

（5）草開清志, 白石 裕：日本金属学会誌，41(1977), 1229.

(6) J.Zarzyski : Discuss. Faraday Soc., 32 (1961) , 38.

(7) R. K. Datta, D. M. Roy, S. P. Faila and O.F. Tuttle : J.Amer. Ceram. Soc., $47(1964), 153$.
（8）河原正泰，森永健次，柳厅瀨 勉：日本金属学会 誌, 41 (1977) , 1047.

（9）日本学術振興会編: 鉄鋼迅速分析法続, 丸善, (1966), p.1.

(10) 箖永煡次，杉之原幸夫，柳ヶ瀬 勉：日本金属学会 誌, 40(1976)， 775 .

(11) 角田成夫，三森 隆，森永健次，柳ヶ瀬 勉：日本 金属学会誌, 44 (1980), 94 .

（12）森永健次，杉之原幸夫，柳瀬 勉：日本金属学会 誌, $40(1976), 480$.

\title{
溶融 $\mathrm{MgCl}_{2}-\mathrm{LiCl}$ および $\mathrm{MgCl}_{2}-\mathrm{CsCl} 2$ 成分系の表面張力
}

\author{
江 島 唇 彦*武并和 彦**
}

\begin{abstract}
J.Japan Inst. Metals, Vol.46, No.4(1982), pp.373-379
\end{abstract}
Surface Tension of $\mathrm{MgCl}_{2}-\mathrm{LiCl}$ and $\mathrm{MgCl}_{2}-\mathrm{CsCl}$ Binary Melts

Tatsuhiko Ejima* and Kazuhiko Takei**

The surface tension of $\mathrm{MgCl}_{2}-\mathrm{LiCl}$ and $\mathrm{MgCl}_{2}-\mathrm{CsCl}$ binary melts has been measured by means of the maximum bubble pressure method over the temperature range from liquidus to about $1200 \mathrm{~K}$. Results obtained are summarized as follows:

(1) For both systems, the surface tension shows an approximately linear decrease with increasing temperature at each composition. The surface tension and its temperature coefficient increase as the content of $\mathrm{LiCl}$ or $\mathrm{CsCl}$ in the melt increases.

(2) Comparing the surface enthalpy per unit area and the surface entropy per unit area of these binary melts with those of other alkari metal chlorides, it is found that these composition dependences are classified into two groups. One is that to which the $\mathrm{LiCl}$ or $\mathrm{NaCl}$ containing melt belongs, and the other is that to which the $\mathrm{KCl}, \mathrm{RbCl}$ or $\mathrm{CsCl}$ containing melt belongs. In the latter melt, the smaller the cation radious of the added salt is, the more the variation becomes conspicuous.

(3) The excess surface tension calculated shows a large negative value over the entire composition range of the $\mathrm{MgCl}_{2}-\mathrm{LiCl}$ binary system due to the enrichment of $\mathrm{MgCl}_{2}$ in the surface layer.

(4) The excess surface tension of the $\mathrm{MgCl}_{2}-\mathrm{CsCl}$ binary melt shows an anomalous change with composition as compared with the $\mathrm{MgCl}_{2}-\mathrm{LiCl}$ binary system. This anomaly is explained by the formation of $\mathrm{MgCl}_{4}^{2-}$ complex ion in the melt and the application of the adsorption theory.

(Received November 9, 1981)

\section{I. 緒言}

溶融塩系についての理解をより一層深めるため, 著者ら は錯イオン形成傾向の著しい $\mathrm{ZnCl}_{2}$ や $\mathrm{MgCl}_{2}$ にアルカリ 金属塩化物を添加した溶融 $\mathrm{MgCl}_{2}-\mathrm{MCl}$ 抽よび $\mathrm{ZnCl}_{2}-\mathrm{MCl}$ $(\mathrm{M}=\mathrm{Li}, \mathrm{Na}, \mathrm{K}, \mathrm{Rb}, \mathrm{Cs}) 2$ 成分系の表面張力 ${ }^{(1)(2)}$ ，密 度 $^{(3)(4)}$, 導電率 ${ }^{(5)}$, 粘性率 ${ }^{(6)(7)}$, 超音波の伝導之吸叫 ${ }^{(8)(9)}$ などの物理化学的諸性質を測定し，これらの結果に基つい て構成イオン種の組成伴伴う变化やこれらの諸性質を支配 する因子などについて検討してきた。
$\mathrm{MgCl}_{2}-\mathrm{NaCl}^{(2)}, \mathrm{MgCl}_{2}-\mathrm{RbCl}^{(2)}, \mathrm{MgCl}_{2}-\mathrm{KCl}^{(1)} 2$ 成分系 の研究に引続き，添加アルカリ金属イオンの影響をより明 確にするため溶融 $\mathrm{MgCl}_{2}-\mathrm{LiCl}$ 打よび $\mathrm{MgCl}_{2}-\mathrm{CsCl}_{2}$ 成分 系の表面張力を最大泡圧法によって測定したので，その結 果を報告する。

\section{II. 実 験}

表面張力の浿定装置および実験方法については前報(1)(2) で詳述したので本報告では省略する，本研究では超高真空 バリアブル・リークバルブ(日電バリアン製)を気泡生成用

* 東北大学工学部金属工学科 (Department of Metallurgy, Faculty of Engineering, Tohoku University, Sendai)

** 東北大学大学院, 現在：住友金属鉱山秼式会社(Graduate School, Tohoku University, Sendai. Present address : Sumitomo Metal Mining Co., Ltd., Tokyo) 